\title{
Equine Adipose Tissue Derived Mesenchymal Stem Cells and Their Multilineage Differentiation
}

\author{
ASM Golam KIBRIA ${ }^{1,2 *}$, Shah NAWAZ2, Tayfun DİKMEN², Özlem ÖZDEN AKKAYA², \\ Artay YAĞCI ${ }^{2}$ \\ ${ }^{1}$ Chittagong Veterinary and Animal Sciences University, Faculty of Veterinary Medicine, Department of Anatomy and Histology, Chittagong, \\ Bangladesh \\ ${ }^{2}$ Afyon Kocatepe University, Faculty of Veterinary Medicine, Department of Histology and Embryology, Afyonkarabisar, Turkey
}

\begin{abstract}
Mesenchymal stem cells (MSCs) have become a potent source for cell therapy due their inherent properties of self-renewal and ability to undergo unlimited divisions in the field of regenerative medicine. In this study, equine adipose tissue stem cells (EASCs) have been evaluated on the basis of their morphology, proliferation potential and multilineage differentiation capabilities for their future usage in cell therapy. The cells were further differentiated into osteogenic and adipogenic cell lineages as well as into adipose derived neurospheres to ensure the stemness of propagated cells. In our study, we further successfully cultured the neurosphere derived cells which were cultured from neurospheres after enzymatic dissociation. The study exhibits that EASCs offer a suitable choice for cellular regenerative therapy in equines. Nonetheless, there is a still need to molecular characterization of EASCs in order to establish a standard practice in equine medicine.
\end{abstract}

Keywords: Equine, Morphology, Multilineage differentiation, Neurosphere, Stem cells

At Yağ Dokusu Kaynaklı Mezenkimal Kök Hücrelerin İzolasyonu ve Çoklu Farklılaştırması

ÖZ

Mezenkimal kök hücreler kendilerini yenileyebilme ve sınırsız bölünebilme kabiliyetlerinin vasıtasıyla rejeneratif tıp alanında etkili bir kaynak haline gelmiştir. Bu çalışmada at yă̆ dokusu kaynaklı mezenkimal kök hücreler (EASCs) gelecekte hücresel tedavilerde kullanılabilirliği adına, morfolojileri ve çoklu farklılaşma kabiliyetleri bakımından değerlendirmeye alınmıştır. Elde edilen hücrelerin kök hücre özelliğini kesinleştirmek için hücreler osteojenik ve adipojenik farklılaştırmaya tabii tutulmuş ve nörosfer farklılaştırması yapılmıştır. Bunun yanı sıra, çalışmada elde edilen nörosferlerin enzimatik olarak çözülümünden sonra elde edilen nörosfer kaynaklı hücreler kültüre edilmiştir. Çalışma at yağ dokusu kaynaklı kök hücrelerin atlarda rejeneratif tıp için uygun bir seçim olabileceğini öne sürmektedir. Fakat at hekimliğinde pratik uygulama için bir standardın oluşturulmasından önce daha detaylı moleküler karakterizasyon çalışmalarına ihtiyaç duyulmaktadır.

Anahtar Kelimeler: At, Morfoloji, Çoklu farklılaştırma, Nörosfer, Kök hücre

To cite this article: Kibria ASMG. Nawaz.S. Dikmen T. Akkaya Ö.Ö. Yağc A. Equine Adipose Tissue Derived Mesenchymal Stem Cells and Their Multilineage Differentiation. Kocatepe Vet J. (2020) 13(2):304-312

Submission: 12.06.2020 Accepted: 04.09.2020 Published Online: 07.09.2020

ORCID ID; ASMGK: 0000-0003-1303-4341, SH: 0000-0001-5468-8267, TD: 0000-0003-4470-7465, ÖÖA: 0000-0001-6372-

9155, AY: 0000-0002-8081-9774

*Corresponding author e-mail: asmgk1982@gmail.com 


\section{INTRODUCTION}

Stem cell research has become an important tool for modern science in the field of gene targeting, cloning, drug research as well as regenerative medicine. Stem cells are known for their unique and promising adequacies such as capability of self-renewal and ability to differentiate into various types of somatic cells (Biehl and Russell 2009). Besides, stem cells have the ability to migrate into the inflammation sites (Laflamme et al. 2007) and facilitate cellular regeneration (Rompolas et al. 2012) and could be source of treatment and cure to various debilitating and notorious diseases (Laflamme et al. 2007, Chen et al. 2018, di Domenico et al., 2019). Broadly, stem cells are classified as totipotent, pluripotent, multipotent, oligopotent and unipotent stem cells with the addition of re-programmed induced pluripotent stem cells (Zakrzewski et al. 2019). Although embryonic stem cells (ESCs) have higher cellular potency (Zakrzewski et al. 2019), MSCs have several benefits over embryonic cells (ESCs), as serious ethical concerns exist while using ESCs and MSCs have lesser immunogenecity (Macrin et al. 2017). Multipotent stem cells are being frequently used in stem cell research as they are easy to obtain and have enough potency to differentiate into many cell types (Mirzaei et al. 2018). The adult stem cells are considered as multipotent stem cells and they could be procured from many tissues of an individual such as bone marrow, muscles, adipose tissue, etc. (Quimby and Dow 2015). The International Society of Cellular Therapy has set certain criteria to declare stem cells as mesenchymal stem cells which include (a) adherence capability to plastic, (b) expression of CD105, CD73, and CD90, (c) absence of expression of CD $45, \mathrm{CD} 34, \mathrm{CD} 14$ or CD11b, CD79 $\alpha$ or CD19, and HLA class II, and (c) ability to differentiate into different cell lineages like osteocytes, adipocytes, and chondrocytes (Dominici et al. 2006). EASCs are reported to have exhibited expression of mesenchymal markers (CD29, CD44 and $\mathrm{CD} 90$ ) and not the major histocompatibility complex II (MHC-II) and CD34 (hematopoietic marker), hence fulfilling the criteria of MSCs (Alipour et al. 2015).

In animals, application of stem cells is getting more important and gaining momentum day by day. In horse, stem cell therapy for cases like tendinitis (Rivera et al. 2020), laminitis (Angelone et al. 2017) has brought about a new dimension in veterinary medicine. Autologous and allogenic applications of equine adipose tissue derived stem cells (EASCs) have become a focus for therapeutic purposes. There are several promising uses of EASCs for tendinitis which resulted in improvement and nearly full recovery; inspiring many researchers for the use of stem cells (Pacini et al. 2007, Crovace et al. 2010, Rivera et al. 2020). The safety of using stem cells for therapeutic approaches is a concern as they might induce cancer or inflamation. For this reason use of stem cells in equine had been investigated by researchers and their results propose that it is safe and easy to use stem cells in equines (Barberini et al. 2018).

In adipose tissues, presence of stem cell number is almost 35 times higher than the stem cells available in bone marrow. It has been noted that one gram of adipose tissue contains 5000 adipose tissue stem cells approximately (Huang et al. 2013). Considering this fact, in the present study EASCs have been isolated, identified, propagated and differentiated. We also aimed to devise a method to isolate viable, feasible and efficient stem cells which could be used further for in-vitro and in-vivo researches as well as for clinical trials.

\section{MATERIALS and METHODS}

\section{Collection of Adipose Tissue and Isolation of EASCs}

The adipose tissues were collected at postmortem from a 3-4 years old horse brought to Research and clinical center of Afyon Kocatepe University (AKU), Turkey (Record\#107, 16/06/15). Approximately, 8 grams of subcutaneous fat tissue was collected from the gluteal region of horse under optimum sterile conditions in $50 \mathrm{ml}$ centrifuge tube (VWR, USA) containing sterile HBSS (Sigma, USA) with 1\% penicillin-streptomycin (Gibco, UK) and $0.1 \%$ amphotericin-B (Biowest, France). Soon after, the tissue was transported to Histology and Embryology laboratory, Faculty of Veterinary Medicine, AKU, Turkey for stem cell isolation and further studies. Harvested adipose tissues were placed in a $10 \mathrm{~mm}$ petri dish, washed four times with sterile HBSS containing $1 \%$ penicillin-streptomycin and $0.1 \%$ amphotericin-B and cut into small pieces (about 1 $\mathrm{cm}^{3}$ size). The tissues were minced into very small pieces with the help of scissors before enzymatic digestion. Later, samples were transferred into a 50 $\mathrm{ml}$ centrifuge tube and about $5 \mathrm{ml}$ collagenase-IA $(0.01 \%)$ (Gibco, USA) was added and incubated into a shaking water bath at $37{ }^{\circ} \mathrm{C}$ for 2 hours. During enzymatic digestion, the tube was stirred by turning upside down at 15 minutes interval. After the enzymatic dissociation, the digestion mixture was strained with the help of $70 \mu \mathrm{m}$ cell strainers (Grenier Bio-One GmBH, Germany) and collected sample was centrifuged at $300 \mathrm{~g}$ for 10 minutes. Following the centrifuge, the supernatant was discarded and the pellet was suspended in low glucose Dulbecco's Minimum Essentials Medium (LG-DMEM) (Sigma, USA) containing of $10 \%$ Fetal Bovine Serum (FBS) (Biowest, South American Origin), 1\% penicillinstreptomycin (Gibco, UK), $200 \mathrm{mM}$ L-Glutamine (Gibco, UK) and $0.1 \%$ amphotericin-B (Biochrom $\mathrm{GmbH}$, Germany). Afterwards, cells were seeded into $25 \mathrm{~cm}^{2}$ cell culture flasks and incubated in a 
humidified atmosphere with $5 \% \quad \mathrm{CO}_{2}$ at $37{ }^{\circ} \mathrm{C}$. Medium was changed every 3rd day and cells were passaged until they reached the required confluence. Cells from $3^{\text {rd }}$ passages were used for differentiation studies.

\section{Colony Forming Units Assay}

To evaluate the colony forming properties of the isolated stem cells; harvested cells from passage three and five (P3 and P5) were seeded at different densities of 250 cells $/ \mathrm{cm}^{2}, 500$ cells $/ \mathrm{cm}^{2}, 1000$ cells/ $\mathrm{cm}^{2}$, in 6-well plates and continued to culture for 15 days (3 replicates each). The culture medium was replenished every 3 days with aforementioned medium. At the end of the $15^{\text {th }}$ day; cells of the colonies were fixed with $4 \%$ paraformaldehyde (Merck, Germany) and stained with crystal violet (Pre-Med, Turkey). Colonies having at least 16-20 cells were took into consideration for counting (Lange-Consiglio et al. 2013). The microscopic images were obtained using low objectives under stereo microscope and the captured images were analyzed by CS-photoshop.

\section{Doubling Time Calculation of EASCs}

Cells were harvested from primary culture were seeded at $25 \mathrm{~cm}^{2}$ flask at a density of 20,000 cells / $\mathrm{cm}^{2}$ and cultured under $5 \% \mathrm{CO}_{2}$ in humidified incubator at $37^{\circ} \mathrm{C}$. Complete renewal of medium was performed with every three days interval till cells reach $80-90 \%$ confluence. After treatment with 0.05\% trypsin-EDTA (Sigma, USA) passaging was performed and harvested cells were counted by Neubauer chamber by Trypan blue (Sigma-Aldrich, USA) dye exclusion method. This process was continued from P1 till P7. There were three sets of cultures in each passage. Cell culture time was calculated for each passage and doubling time was calculated by using following formula (Roth and Tuggle 2015).

Doubling time $=\frac{\text { duration } * \log (2)}{\log (\text { Final concentration })-\log (\text { Initial concentration })}$

\section{Growth Curve Determination of EASCs}

To generate the growth curve and to observe the behavioral pattern of cell proliferation, EASCs were seeded at the density of 8000 cells per $\mathrm{cm}^{2}$ into fourwell cell culture plates (Thermo Scientific, Denmark), at passage 3, 5 and 7 (P3, P5 and P7). Cells were cultured for 14 days and in every 2 days interval cells were trypsinized and counted by using Neubauer chamber and Trypan blue dye. The cell culture medium was changed every third day of culture. This process was repeated for three sets for each of the mentioned passages.

\section{Neurospheres generation}

Stem cells from P3 and P5 were considered for neurospheres generation. To perform the neurospheres generation, four-well cell culture plates were coated with $0.01 \%$ Poly-L-Lysine (Sigma, USA). The cells were seeded in the plates at a density of 50,000 cells $/ \mathrm{cm}^{2}$. Medium containing DMEM/F-12 (Gibco, UK), 1\% Penicillin-Streptomycin (Gibco, $\mathrm{UK}$ ), $0.1 \%$ Amphotericin-B (Biochrom $\mathrm{GmbH}$, Germany), 1\% Insulin- Transferrin- Selenium (Gibco, USA), $20 \mathrm{ng} / \mathrm{ml} \mathrm{EGF} \mathrm{(Sigma,} \mathrm{USA)} \mathrm{and} 20 \mathrm{ng} / \mathrm{ml}$ FGF (R\&D Systems, USA) was used to generate neurospheres. Plates were cultured in $95 \%$ humidity and $5 \% \mathrm{CO}_{2}$ supply conditions at $38.5^{\circ} \mathrm{C}$. Half of the differentiation medium was changed with great care to avoid aspirating neurospheres, in every two days. The neurospheres were photographed at $24^{\text {th }}, 48^{\text {th }}$, $96^{\text {th }}$ and $120^{\text {th }}$ hours post induction under inverted microscope using DP-25 software. There were 3 replicates for each.

\section{Culture of Neurospheres into Neurospheres Derived Cells}

Neurospheres were collected into a $15 \mathrm{ml}$ centrifuge tube carefully along with culture medium from the dishes. By flushing $2 \mathrm{ml}$ of serum free medium into the wells; remaining neurospheres were harvested completely. Neurospheres that were collected into the centrifuge tube were centrifuged at $1000 \mathrm{rpm}$ for 3 minutes and supernatant was discarded. After that the cell pellet was resuspended with $1 \mathrm{ml}$ of trypsinEDTA and incubated at $37{ }^{\circ} \mathrm{C}$ for 1 minute. Afterwards, $1 \mathrm{ml}$ of FBS containing culture medium was added into the tube to stop the enzymatic activity of trypsin-EDTA. The final mixture was centrifuged at $1000 \mathrm{rpm}$ for 3 mins. Cell pellet was resuspended in $2 \mathrm{ml}$ of serum containing culture medium after discarding supernatant. Then, cell suspensions were re-plated on poly-D-lysine (Company, Country) coated 6-well culture plates with $2 \mathrm{ml}$ serum containing medium in each well used for EASCs culture. Adipose neurospheres derived cells were grown under normal culture condition at $37^{\circ} \mathrm{C}$ and $5 \% \mathrm{CO}_{2}$ (De Oliveira Carvalho 2012) where medium was changed every 2 days. After reaching confluence, cells were harvested using trypsin-EDTA.

\section{Osteogenic Differentiation of MSCs}

After third passage, MSCs were collected and seeded into a 24-well cell culture plate at 29000 cells/well with the help of differentiation medium containing 10\% FBS (Biowest, South America), 1\% penicillinstreptomycin (Gibco, UK), 0.1\% amphotericin-B (Biochrom GmbH, Germany), 200 mM L-Glutamine (Gibco, UK), $0.1 \mu \mathrm{M}$ dexamethasone (Sigma, Belgium), $0.05 \mathrm{mM}$ ascorbic acid (Dr. Ehrenstorfer $\mathrm{GMbH}$, Germany) and $10 \mathrm{mM}$ B-glycerophosphate (Gibco, UK) in $\alpha$-MEM (Lonza, Belgium). Medium was changed with every three days interval and condition was regularly checked under inverted microscope. To ensure the differentiation, cells were stained with Alizarin Red S at $14^{\text {th }}$ and $21^{\text {th }}$ day of 
differentiation. Photographs were taken using DP-25 software under inverted microscope.

\section{Adipogenic Differentiation of EASCs}

After third passage, EASCs were collected and seeded into 24 well cell culture plate at 29000 cells/well using adipogenic induction medium containing LGDMEM, 10\% FBS, 1\% Penicillin-Streptomycin (Gibco, UK), 0.1\% amphotericin-B (Biochrom $\mathrm{GmbH}$, Germany), $0.5 \quad \mathrm{mM}$ 3-isobutyl-1methylxanthine (IBMX) (Sigma, Germany), $1 \mu \mathrm{M}$ dexamethasone, $10 \mu \mathrm{g} / \mathrm{ml}$ insulin (Gibco, USA) and $100 \mu \mathrm{M}$ indomethacin (Cayman Chemical Company, USA). Additionally, at Day 7 and 15 of differentiation, EASCs were cultured in adipogenic maintenance medium composed of LG-DMEM, 10\% FBS, $0.05 \%$ Pen/Strep and $10 \mu \mathrm{g} / \mathrm{ml}$ insulin. Medium was changed by three days interval and status of cells was checked under inverted microscope according to the cell culture manual (Cat\# SCR020, Chemicon ${ }^{\circledR}$
International). To evaluate the differentiation, cells were stained with $O$ il red $O$ at $14^{\text {th }}$ and $19^{\text {th }}$ day for identification of adipogenic character. Photographs were taken using DP-25 software under inverted microscope.

\section{RESULTS}

\section{Morphology of Equine Adipose Tissue Derived MSCs}

In the culture flask, after the isolation, cells exhibited adherence to plastic surface. In subsequent passages, cells were observed for good proliferation potential and were observed to reach $90-95 \%$ confluence in the P2, P3 and P4 within 3-4 days. EASCs were observed to have spindle shaped of fibroblast like morphology under inverted microscope, a characteristic feature of stem cells. After, initial culture, EASCs from P2 onward exhibited homogenous fibroblast-like morphology (Fig. 1).

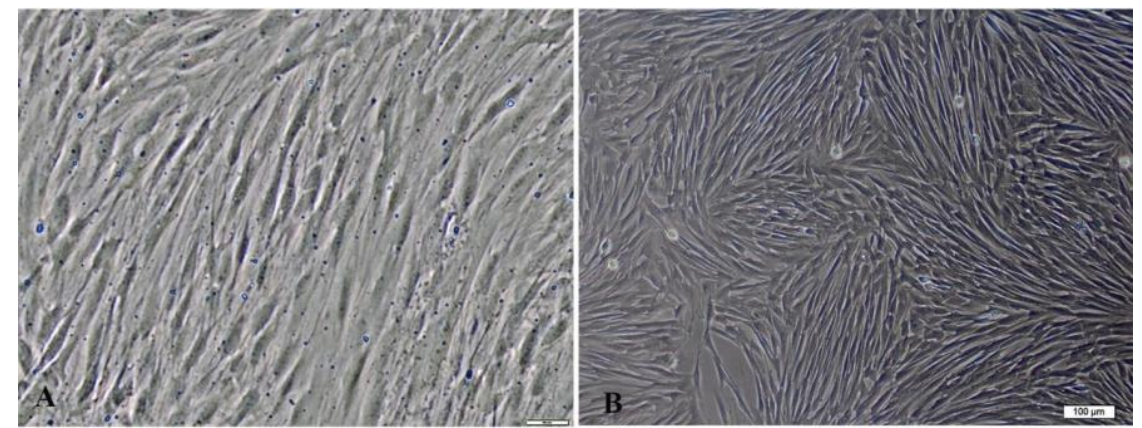

Figure 1. . EASCs dominantly exhibited fibroblast-like morphology starting from P2 and onwards. A: EASCs at P2; B: EASCs at P6.

\section{Colony Forming Unit Assay}

EASCs were evaluated for numbers of colony formation in relation with different seeding densities at the beginning of culture and at different passages (P3 and P5). At both passages, it was observed that numbers of colonies were observed to have significant increase which was proportional to increase in seeding density of EASCs (Fig. 2A-F). However, it was found that EASCs from P3 exhibited more colonies compared to P5 which was observed after staining with crystal violet stain.
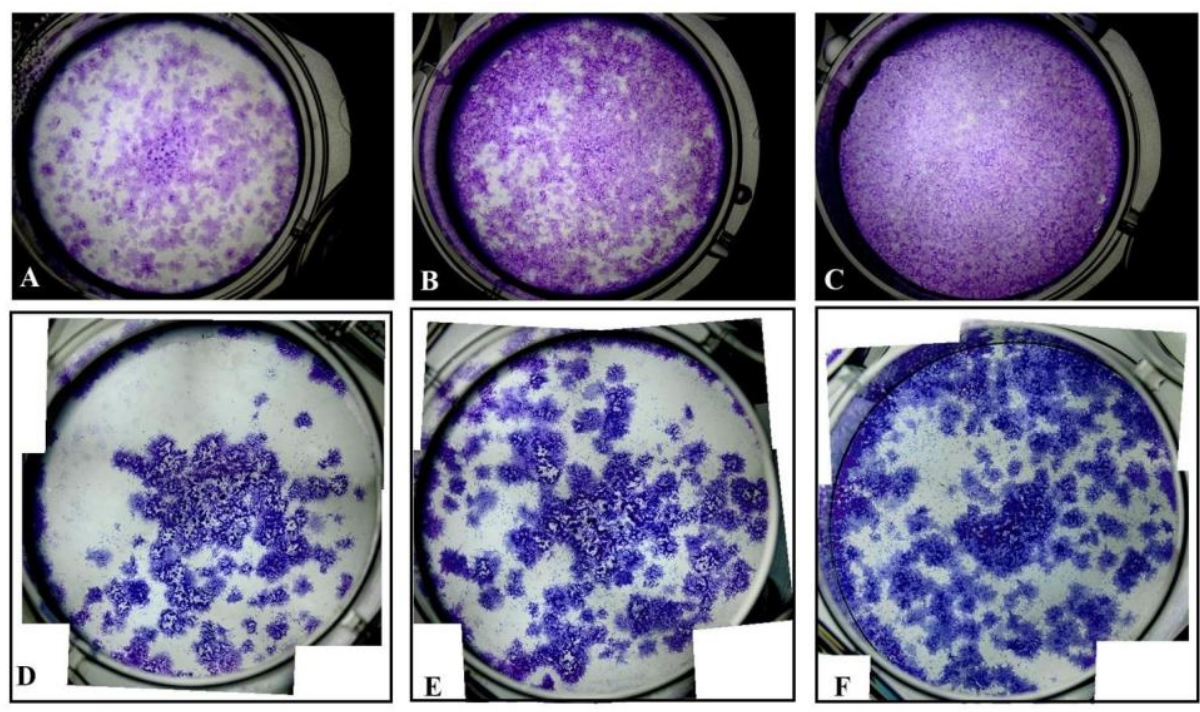

Figure 2. Colony forming unit assay showed that in both P3 (A,B,C) and P5 (D,E,F); colony numbers increased depending upon seeding densities. For both passages concentration of 250 cells $/ \mathrm{cm}^{2} \mathbf{( A , D )}$ resulted with least colonies while 500 cells $/ \mathrm{cm}^{2}$ density $(\mathbf{B}, \mathbf{E})$ demonstrated better results but 1000 cells $\left./ \mathrm{cm}^{2} \mathbf{( C , F}\right)$ had highest number of colonies. It was visible that $\mathrm{P} 3$ cells gave rise much more colonies compared to P5 cellsfor all concentrations. 


\section{Doubling Time Analysis}

During doubling time calculation, it was observed that EASCs exhibited significantly highest proliferation rates with minimal doubling time at P5 followed by P6 and P4 when compared to other passages $(p<0.05)$. However, no significant difference was observed among P4, P5 and P6 (Fig. 3).

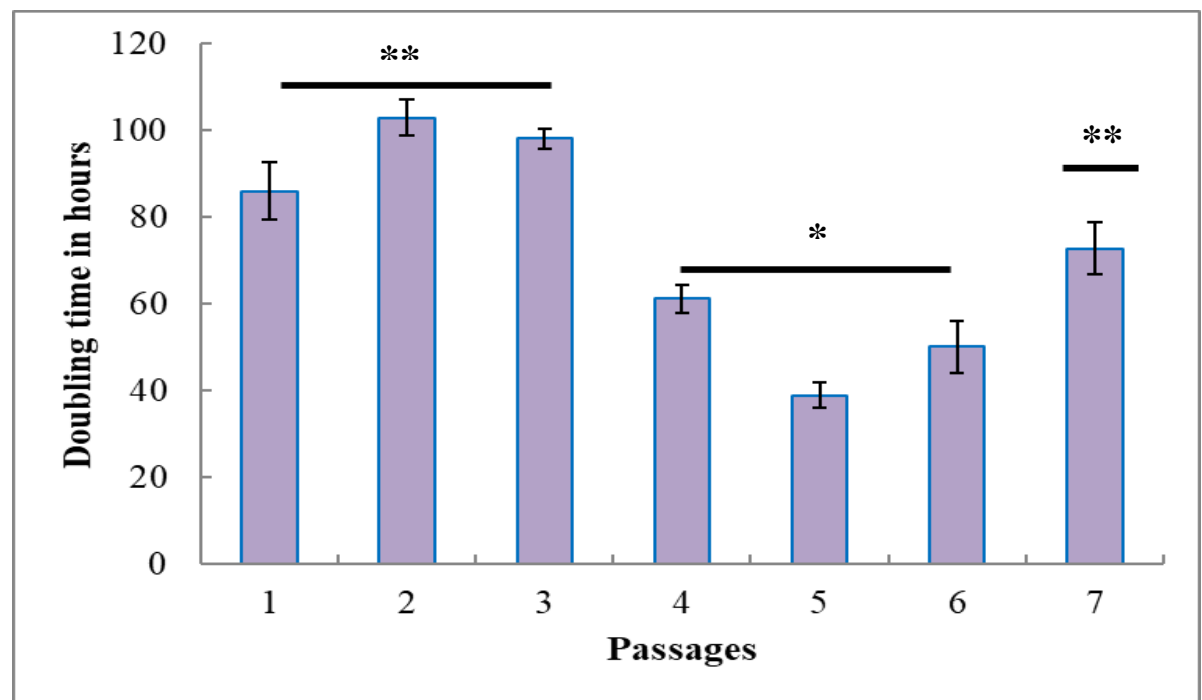

Figure 3. Doubling time analysis of EASCs at different passages (P1-P7). Results are presented as mean \pm standard deviation. Significance is shown by differences in $*(\mathrm{p}<0.05)$.

\section{Growth Curve Analysis}

The growth curve study for EASCs showed that the initial phase is was stand for 2-4 days for all recorded passages (P3, P5 and P7). The subsequent log phase was noticed for 4-10 days in and then declined. From the growth pattern it was revealed that the cells of P5 have got the longer stationary phase revealing higher potentiality for proliferation. With the subsequent advancement of passaging, cells had slower and lesser prolificacy (Fig. 4).

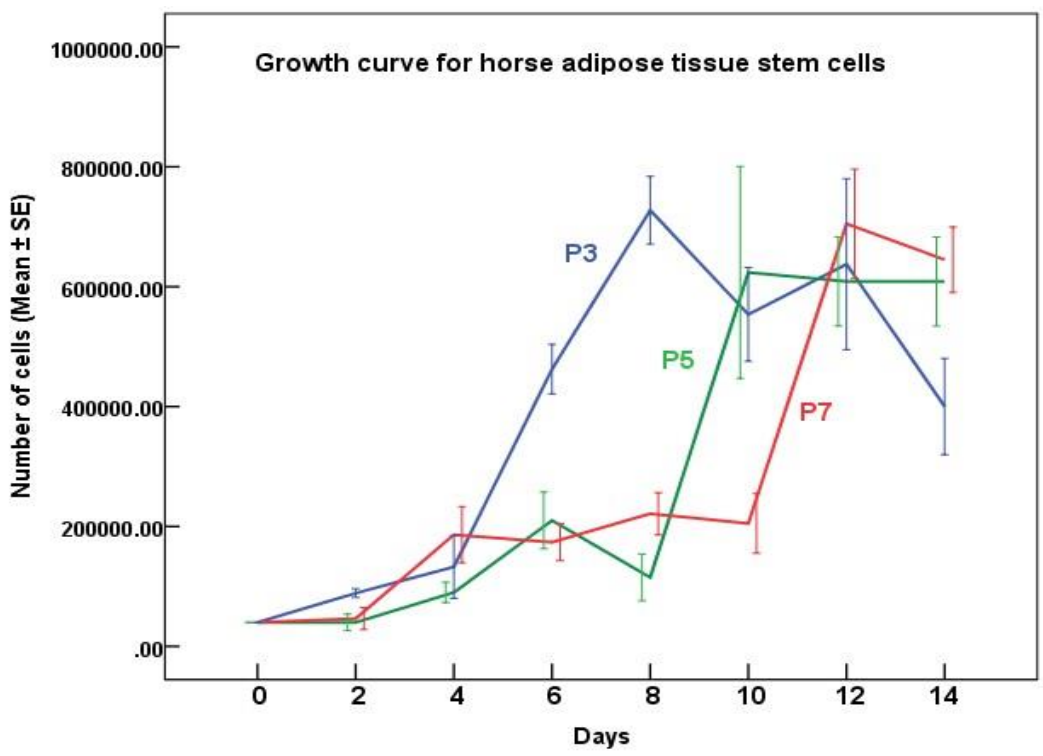

Figure 4. Growth curve analysis of EASCs at P3, P5 and P7. The study showed that P5 have got the longer stationary phase and the cells demonstrated slower growth by the advancing passages

\section{Neurospheres Generation}

As a part of multilineage differentiation studies, neurospheres were generated on lysine coated plates with define medium (Fig. 5). For EASCs at P5, neurospheres were observed as spheroid, threedimensional (3-D) structures that usually formed by the 48 th $\mathrm{h}$ of culture but took about 4 days to become fully matured and free floating spheroids. After the 5th day, the spheres were observed to disintegrate. Neurospheres formation was found to be comparatively slower at P3 when compared to P5 and P7. It was noticed that with the advancement of time, the 3-D structure of neurospheres become degraded gradually and disappeared finally. 

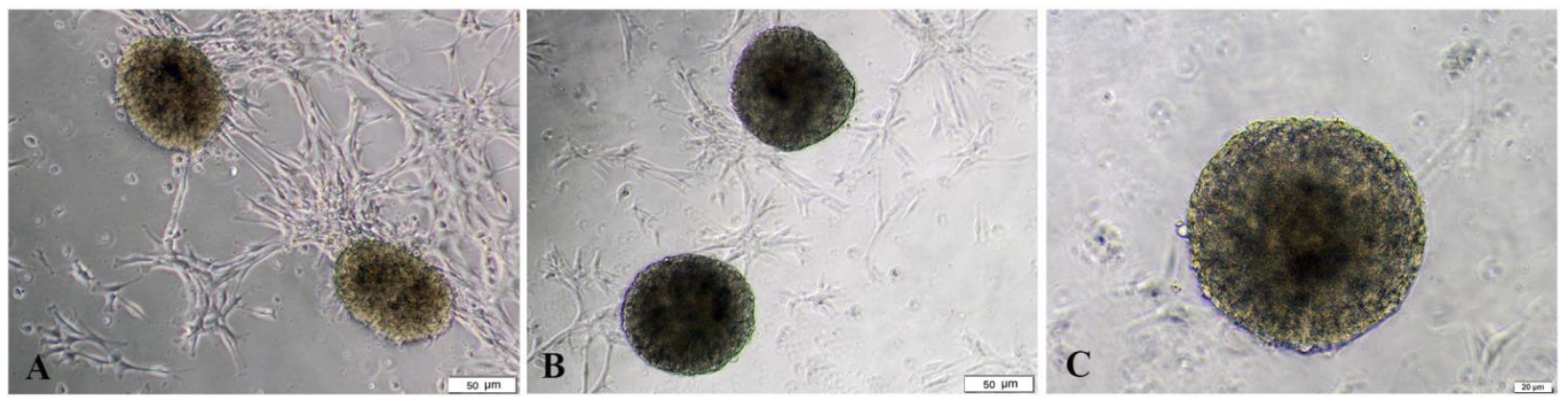

Figure 5. Neurospheres were successfully generated under the influence of EGF and FGF. Bar: $50 \mu \mathrm{m}$ (A, B); $20 \mu \mathrm{m}$ (C).

\section{Culture of Neurospheres into Neurospheres Derived Cells}

The generated neurospheres were collected and treated with trypsin-EDTA. After the trypsinization, cells were re-plated on poly-D-lysine coated plates with culture medium containing serum. The disintegrated cells were found to be reattached with culture surface and began to grow within $22 \mathrm{~h}$ (Fig. 6). After 72 hours of culture, it was observed that neurospheres derived cells started to grow from periphery of neurospheres and became confluent within couple of days during monolayer cell expansion. The cells observed to have fibroblast like morphology meanwhile, center of neurospheres was observed to have dark appearance. The cells were cultured till P5 and were observed to have good proliferation potential throughout the cultured time.
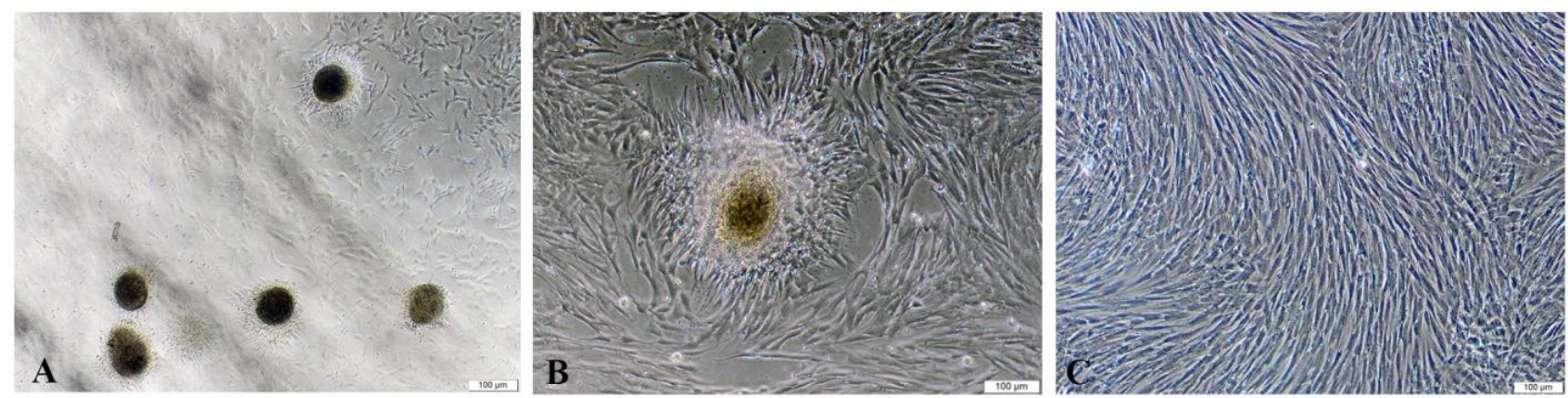

Figure 6. The EASCs neuropsheres were able to regenerate neurosphere derived cells. After the seeding, cells started to grow from periphery of neurospheres (A, B). These cells exhibited fibroblast-like morphology (C).

\section{Osteogenic Differentiation Potential}

EASCs were observed to have good osteognic potential after 21 days of culture in induction medium in-vitro. The characteristic osteogenic differentiation was observed by extracellular calcium deposition stained orange red with Alizarin Red-S staining while the control sample remained unaffacted (Fig. 7).
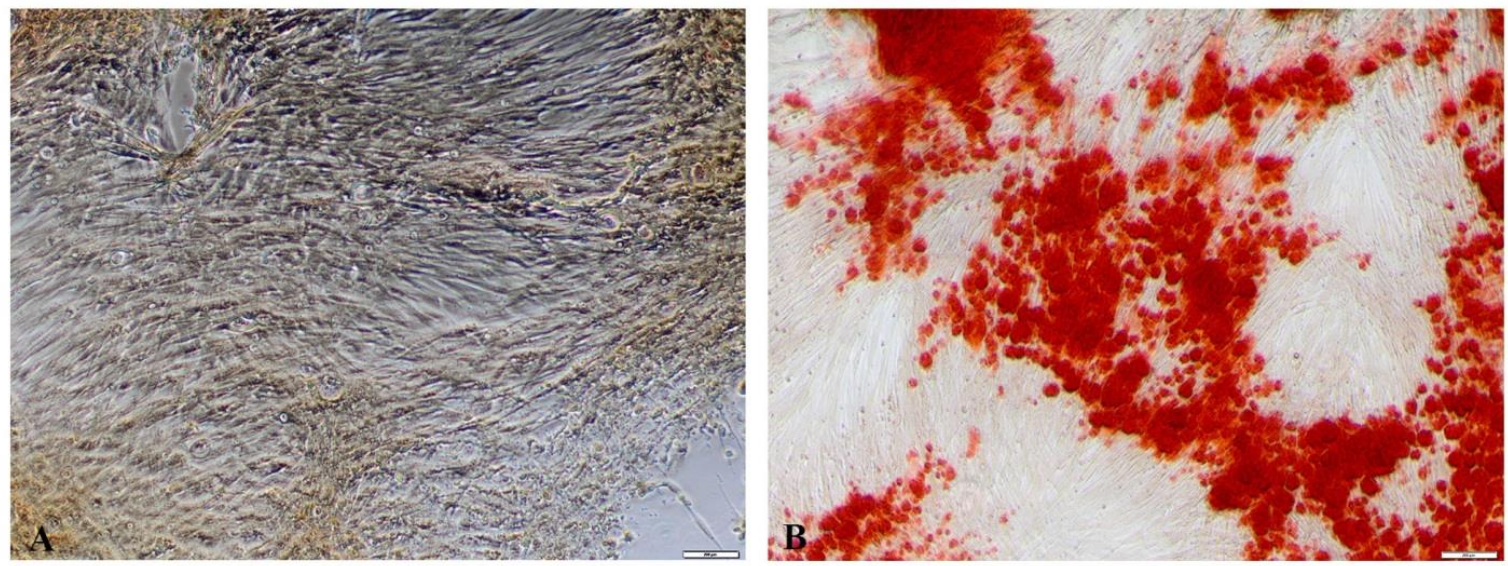

Figure 7. During the multi-lineage differentiation studies, EASCs were subjected with osteogenic differentiation. After 21 days of differentiation, calcium deposits were demonstrated with alizarin red-s staining (B). The control sample was unaffacted by the stain (A).

\section{Adipogenic differentiation Potential}


The adipogenic differentiation of EASCs was confirmed by Oil red-O staining. Nuclei stained in black after hematoxylin staining and the accumulation of lipid droplets in the cytoplasm of the cells stained in bright red colour at 14th and 19th days of the differentiation study. Meanwhile the control sample remained unaffacted after staining (Fig. 8).
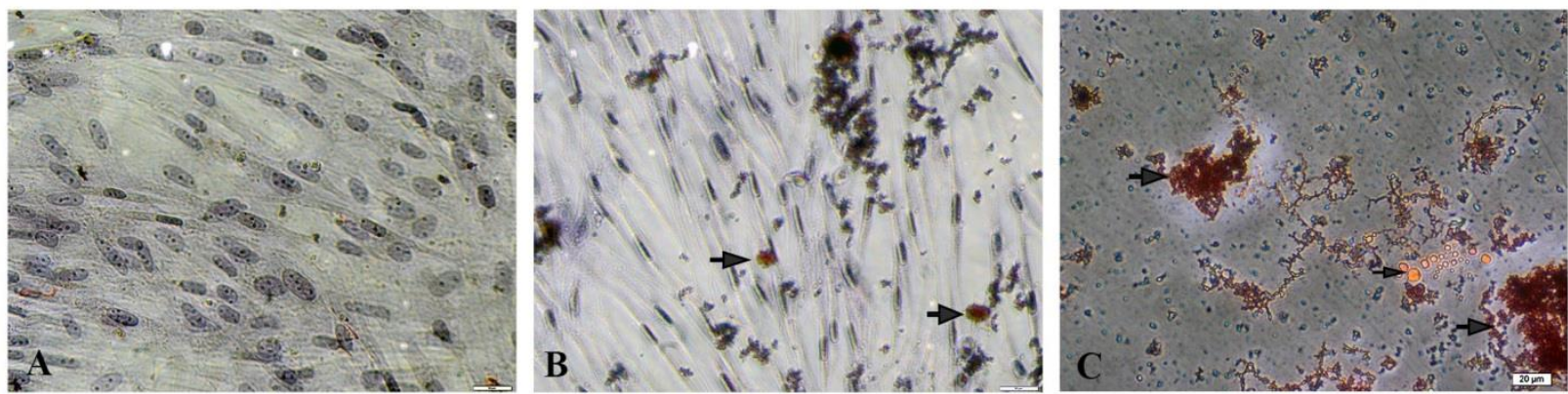

Figure 8. EASCs were also subjected to adipogenic differentiation for 14 and 19 days. To demonstrate the adipogenic differentiation, Oil Red-O stainings were performed at both time intervals. The oil droplets were in red for both day 14 samples (B) and day 21 samples (C). There was no staining in the control group (A). Arrow: Oil droplets.

\section{DISCUSSION}

Adipose tissues are gaining more popularity among researches for stem cell therapies and applications due to ease of isolation and high proliferation potential. In consistent with previous findings from human adipose stem cells (De Coppi et al. 2007) and from equine (Lange-Consiglio et al. 2012), EASCs exhibited fibroblast morphology and strong adherent properties. During primary culture at initial seeding, EASCs were observed to less homogenous in morphology and showed a combination of branched spindle shaped fibroblast like cells and ovoid or circular cells similar to previous reports (Dominici et al. 2006, Iacono et al. 2012, Zuk et al. 2001). At P0, the aggregated cells with nodular or globular structures were recognized as budding nest. This particular phenotype criterion has already been reported by Alipour et al. (2015) and Tepliashin et al. (2005) who suggested that this accumulation give rise to populate special type of cells with uniform morphology.

The growth curve and doubling time analysis showed that EASCs possess high proliferation potential. Although, we couldn't perform comparative study for specific proliferation potential of EASCs with any other stem cell, in a comparative study, Burk et al. (2013) reported that adipose derived stem cells express higher proliferation potential when compared to bone marrow derived stem cells. The EASCs are reported as multipotent stem cells by several researches (Dixon-Shanies et al. 1975, Gimble and Guilak 2003) and EASCs getting more importance day by day for application in regenerative cell therapy (De Mattos Carvalho et al. 2011, Vidal et al. 2007).

It is reported that to be established as a stem cell, cultured cells should be able to differentiate into multiple lineages such as adipogenic, osteogenic or neurogenic lineages (De Schauwer et al. 2011, Dominici et al. 2006). Cells are reported to exhibit some phenotypic, metabolic and genetic changes during differentiation process which could be assessed by expression of specific markers (De Schauwer et al. 2011). However, such changes can also be detected by staining of the differentiated cells with tissue specific staining agents. EASCs were successfully differentiated into osteogenic lineage which was analyzed by Alizarin Red-S staining. Adipogenic differentiation was proved by Oil red-O to detect intracellular lipid droplets ensuring that the cells differentiated into adipogenic lineage. These findings and procedures were similar to previous studies in this regard (Koç et al. 2008, Moonesi Rad et al. 2019, Fink and Zachar 2011, Nawaz et al. 2020, Ozden-Akkaya et al. 2019).

Furthermore, neurospheres generation from adipose tissue make provision for the treatment of alleviation of neurogenic disorder or diseases that may need proper administration media and process. Researchers had reported similar results from different sources of various species such as human (Lee et al. 2011), bovine (Ozden-Akkaya et al. 2019), canine (Altunbaş et al. 2016) in the context of neurosphere generation under the influence of EGF and FGF, supporting our findings. Although equine stem cells of different sources like equine umbilical cord (Martino et al. 2014), equine amniotic membrane (Lange-Consiglio et al. 2012) known to be able to differentiate into neurogenic cells; there were no reports found on neurospheres generation for equine. This study shows that EASCs are able to form neurospheres. Moreover, it was reported (De Oliveira Carvalho. 2012) that neurospheres derived cells have that potential capability to propagate and regenerate into neuron like cells having neuronal marker $\beta$-tubulin-III and amyloid precursor protein. The yielding of monolayer plastic adherent fibroblast like cells from neurospheres (Girard et al. 2011) is one of the criteria for evaluation of neurospheres that was also confirmed in this study. Although we were unable to 
prove molecular characteristics of the cultured cells; neurospheres gave rise to fibroblast-like cells which were adherent to the plastic surface and demonstrate a good proliferation rate while the cells were able to undergo sub-culture for many passages.

\section{CONCLUSIONS}

The morphologic criteria of the isolated and proliferated mesenchymal stem cells and its differentiation into multiple cell lineages confirmed their identity as multipotent stem cells. These findings also favors the regenerative therapy with MSCs that are able to migrate and take residence to the injured or application sites with propagation of desired cells of the target tissues. Also, a small amount of adipose tissue is able to give large amount of cells for the therapy. However, more detailed and in-depth investigations are important to establish stem cells proliferation and differentiation within the spatial distribution of adipose tissue in animal body to understand detailed molecular and biological system in extensive clinical uses.

Conflict of Interest: The authors declare that they have no conflict of interest

\section{REFERENCES}

Alipour F, Parham A, Mehrjerdi HK, Dehghani H. Equine adipose-derived mesenchymal stem cells: phenotype and growth characteristics, gene expression profile and differentiation potentials. Cell journal. 2015; 16(4): 456465.

Altunbaş K, Yaprakçı MV, Çelik S. Isolation and Characterization of Olfactory Stem Cells from Canine Olfactory Mucosa. Kafkas Univ Vet Fak Derg. 2016; 22(2): 237-243.

Angelone M, Conti V, Biacca C, Battaglia B, Pecorari L, Piana F, Gnudi G, Leonardi F. The contribution of adipose tissue-derived mesenchymal stem cells and platelet-rich plasma to the treatment of chronic equine laminitis: A proof of concept. 2017; 18.

Barberini DJ, Aleman M, Aristizabal F, Spriet M, Clark KC, Walker NJ, Galuppo LD, Amorim RM, Woolard KD, Borjesson DL. Safety and tracking of intrathecal allogeneic mesenchymal stem cell transplantation in healthy and diseased horses. Stem Cell Res Ther. 2018; 9: 96.

Biehl JK, Russell B. Introduction to stem cell therapy. The Journal of cardiovas nurs. 2009; 24(2): 98-105.

Burk J, Ribitsch I, Gittel C, Juelke H, Kasper C, Staszyk C, Brehm W. Growth and differentiation characteristics of equine mesenchymal stromal cells derived from different sources. Vet journal. 2013; 195(1): 98-106.

Chen S, Cui G, Peng C, Lavin MF, Sun X, Zhang E, Yang Y, Guan Y, Du Z, Shao H. Transplantation of adiposederived mesenchymal stem cells attenuates pulmonary fibrosis of silicosis via anti-inflammatory and anti- apoptosis effects in rats. Stem Cell Res Ther. 2018; 9: 110.

Crovace A, Lacitignola L, Rossi G, Francioso E. Histological and immunohistochemical evaluation of autologous cultured bone marrow mesenchymal stem cells and bone marrow mononucleated cells in collagenase-induced tendinitis of equine superficial digital flexor tendon. Vet med international. 2010; 2010: 250978.

De Coppi P, Bartsch G, Siddiqui MM, Xu T, Santos CC, Perin L, Mostoslavsky G, Serre AC, Snyder EY, Yoo JJ, Furth ME, Soker S, Atala A. Isolation of amniotic stem cell lines with potential for therapy. Nat Biotechnol. 2007; 25.

De Mattos Carvalho A, Alves ALG, de Oliveira PGG, Álvarez LEC, Amorim RL, Hussni CA, Deffune E. Use of Adipose Tissue-Derived Mesenchymal Stem Cells for Experimental Tendinitis Therapy in Equines .Journal of Equine Vet Sci. 2011; 31: 26-34.

De Oliveira Carvalho SDB. Establishing stem cell based systems to study neuropathologies. (Master Research), Universidade de Aveiro, Portugal. 2012.

De Schauwer C, Meyer E, de Walle GRV, Soom AV. Markers of stemness in equine mesenchymal stem cells: a plea for uniformity. Theriogenology. 2011; 75(8): 1431-1443.

Di Domenico A, Carola G, Calatayud C, Pons-Espinal M, Muñoz JP, Richaud-Patin Y, Fernandez-Carasa I, Gut M, Faella A, Parameswaran J, Soriano J, Ferrer I, Tolosa E, Zorzano A, Cuervo AM, Raya A, Consiglio A. Patient-specific ipsc-derived astrocytes contribute to non-cell-autonomous neurodegeneration in parkinson's disease. Stem cell reports. 2019; 12: 213-229.

Dixon-Shanies D, Rudick J, Knittle JL. Observatons on the growth and metabolic functions of cultured cells derived from human adipose tissue. Proceedings of the Society for Experimental Biology and Medicine. Society for Expt Biol and Med. 1975; 149(2): 541-545.

Dominici M, Le Blanc K, Mueller I, Slaper-Cortenbach I, Marini F, Krause D, Deans R, Keating A, Prockop D, Horwitz E. Minimal criteria for defining multipotent mesenchymal stromal cells. The International Society for Cellular Therapy position statement. Cytotherapy. 2006; 8(4): 315-317.

Fink T, Zachar V. Adipogenic differentiation of human mesenchymal stem cells. In: Vemuri M, Chase LG, Rao MS, eds. Mesenchymal stem cell assays and applications. Totowa, NJ: Humana Press, 2011; 243-251.

Gimble J, Guilak F. Adipose-derived adult stem cells: isolation, characterization, and differentiation potential. Cytotherapy. 2003; 5(5): 362-369.

Girard SD, Devéze A, Nivet E, Gepner B, Roman FS, Féron F. Isolating nasal olfactory stem cells from rodents or humans. Journal of visualized experiments: JoVE. 2011; 54.

Huang SJ, Fu RH, Shyu WC, Liu SP, Jong GP, Chiu YW, Wu HS, Tsou YA, Cheng CW, Lin SZ. Adiposederived stem cells: isolation, characterization, and differentiation potential. Cell transplantation. 2013; 22(4): 701-709. 
Iacono E, Brunori L, Pirrone A, Pagliaro PP, Ricci F, Tazzari PL, Merlo B. Isolation, characterization and differentiation of mesenchymal stem cells from amniotic fluid, umbilical cord blood and Wharton's jelly in the horse. Reproduction. 2012; 143(4): 455-468.

Koç A, Emin N, Elçin AE, Elçin YM. In Vitro Osteogenic Differentiation of Rat Mesenchymal Stem Cells in a Microgravity Bioreactor. Journal of Bioactive and Compatible Polymers. 2008; 23(3): 244-261.

Laflamme MA, Chen KY, Naumova AV, Muskheli V, Fugate JA, Dupras SK, Reinecke H, Xu C, Hassanipour M, Police S, O'Sullivan C, Collins L, Chen Y, Minami E, Gill EA, Ueno S, Yuan C, Gold J, Murry CE. Cardiomyocytes derived from human embryonic stem cells in pro-survival factors enhance function of infarcted rat hearts. Nat. Biotechnol. 2007; 25(9): 1015-1024.

Lange-Consiglio A, Corradetti B, Bizzaro D, Magatti M, Ressel L, Tassan S, Parolini O, Cremonesi F. Characterization and potential applications of progenitorlike cells isolated from horse amniotic membrane. Journal of Tissue Eng Reg Med. 2012; 6(8): 622-635.

Lange-Consiglio A, Corradetti B, Meucci A, Perego R, Bizzaro D, Cremonesi F. Characteristics of equine mesenchymal stem cells derived from amnion and bone marrow: in vitro proliferative and multilineage potential assessment. Equine vet journal. 2013; 45(6): 737-744.

Lee ST, Chu K, Jung KH, Song YM, Jeon D, Kim SU, Kim M, Lee SK, Roh JK. Direct generation of neurospherelike cells from human dermal fibroblasts. PloS one. 2011; 6(7): e21801.

Macrin D, Joseph JP, Pillai AA, Devi A. Eminent sources of adult mesenchymal stem cells and their therapeutic imminence. Stem cell reviews and reports. 2017; 13: 741 756.

Martino NA, Reshkin SJ, Ciani E, Dell'Aquila ME. CalciumSensing Receptor-Mediated Osteogenic and Early-Stage Neurogenic Differentiation in Umbilical Cord Matrix Mesenchymal Stem Cells from a Large Animal Model. PloS one. 2014; 9(11): e111533.

Mirzaei H, Sahebkar A, Sichani LS, Moridikia A, Nazari S, Sadri Nahand J, salehi H, Stenvang J, Masoudifar A, Mirzaei HR, Jaafari MR. Therapeutic application of multipotent stem cells. J Cell Physiol. 2018; 233: 28152823.

Moonesi Rad R, Atila D, Evis Z, Keskin D, Tezcaner A. Development of a novel functionally graded membrane containing boron-modified bioactive glass nanoparticles for guided bone regeneration. Journal of tissue eng reg med. 2019; 13(8): 1331-1345.

Nawaz S, Özden Akkaya Ö, Dikmen T, Altunbaş K, Yağci A, Kibria ASMG, Erdoğan M, Çelik HA. Molecular characterization of bovine amniotic fluid derived stem cells with an underlying focus on their comparative neuronal potential at different passages. Annals of Anatomy - Anatomischer Anzeiger. 2020; 228: 151452.

Ozden-Akkaya O, Dikmen T, Nawaz S. Investigation of Sox2, B-III Tubulin and Nestin Expressions in Neuropsheres Differentiated from Bovine Adipose Derived
Mesenchymal Stem Cells by Immunofluorescence Staining. Kocatepe Vet Journal. 2019; 12(3): 336-342.

Pacini S, Spinabella S, Trombi L, Fazzi R, Galimberti S, Dini F, Carlucci F, Petrini M. Suspension of bone marrow-derived undifferentiated mesenchymal stromal cells for repair of superficial digital flexor tendon in race horses. Tissue engineering. 2007; 13(12): 2949-2955.

Quimby JM, Dow SW. Novel treatment strategies for feline chronic kidney disease: A critical look at the potential of mesenchymal stem cell therapy. Vet journal (London, England: 1997). 2015; 204(3): 241-246.

Rivera C, Tuemmers C, Bañados R, Vidal-Seguel N, Montiel-Eulefi E. Reduction of recurrent tendonitis scar using autologous mesenchymal stem cells derived from adipose tissue from the base of the tail in holsteiner horses (Equus ferus caballus). Int J Morphol. 2020; 38: 186192.

Rompolas P, Deschene ER, Zito G, Gonzalez DG, Saotome I, Haberman AM, Greco V. Live imaging of stem cell and progeny behaviour in physiological hair-follicle regeneration. Nature. 2012; 487: 496-499.

Roth JA, Tuggle CK. Livestock models in translational medicine. ILAR journal. 2015; 56(1): 1-6

Tepliashin AS, Chupikova NI, Korzhikova SV, Sharifullina SZ, Rostovskaia MS, Topchiashvili ZA, Savchenkova IP. Comparative analysis of cell populations with a phenotype similar to that of mesenchymal stem cells derived from subcutaneous fat. Tsitologiia. 2005; 47(7): 637-643.

Vidal MA, Kilroy GE, Lopez MJ, Johnson JR, Moore RM, Gimble JM. Characterization of equine adipose tissuederived stromal cells: adipogenic and osteogenic capacity and comparison with bone marrow-derived mesenchymal stromal cells. Vet surgery. 2007; 36(7): 613-622.

Zakrzewski W, Dobrzyński M, Szymonowicz M, Rybak Z. Stem cells: Past, present, and future. Stem Cell Res Ther. 2019; 10: 68.

Zuk PA, Zhu M, Mizuno H, Huang J, Futrell JW, Katz AJ, Benhaim P, Lorenz HP, Hedrick MH. Multilineage cells from human adipose tissue: implications for cellbased therapies. Tissue engineering. 2001; 7(2): 211-228. 